\title{
Reduced carbon sequestration in a Mediterranean seagrass (Posidonia oceanica) ecosystem impacted by fish farming
}

\author{
Eugenia T. Apostolaki ${ }^{1,2, *}$, Marianne Holmer ${ }^{3}$, Núria Marbà ${ }^{4}$, Ioannis Karakassis ${ }^{2}$ \\ ${ }^{1}$ Institute of Oceanography, Hellenic Centre for Marine Research, PO Box 2214, 71003, Heraklion, Crete, Greece \\ ${ }^{2}$ Marine Ecology Laboratory, Biology Department, University of Crete, PO Box 2208, 71409, Heraklion, Crete, Greece \\ ${ }^{3}$ Institute of Biology, University of Southern Denmark, Campusvej 55, 5230 Odense M, Denmark \\ ${ }^{4}$ Department of Global Change, Institut Mediterrani d'Estudis Avançats (CSIC-UIB), Miquel Marquès 21, 07190 Esporles \\ (Illes Balears), Spain
}

\begin{abstract}
We studied the relationship between sediment nutrient enrichment and carbon sequestration, using the ratio of gross primary production to respiration $(P / R)$, in a fishfarming impacted and an unaffected Mediterranean seagrass (Posidonia oceanica) ecosystem in the Aegean Sea, Greece. Carbon (C), nitrogen (N) and phosphorus (P) sedimentation, nutrient pools in sediment and dissolved nutrients in pore water were significantly and positively intercorrelated, indicating close linkage between sedimentation and sediment nutrient pools in seagrass meadows. $\mathrm{C}, \mathrm{N}$ and $\mathrm{P}$ sediment pools were significantly enhanced in the impacted meadow throughout the year, even during winter when fish farming activity was low. In the impacted sediment, the increase in $\mathrm{C}$ and $\mathrm{N}$ was higher than $\mathrm{P}$, reflecting a faster remineralization and uptake of $\mathrm{P}$ than $\mathrm{C}$ and $\mathrm{N}$. The ecosystem $P / R$ ratio decreased exponentially with sediment nutrient enrichment. Threshold values are given for $\mathrm{C}, \mathrm{N}$ and $\mathrm{P}$ sedimentation rates and sediment pools, and for $\mathrm{N}$ and $\mathrm{P}$ concentrations in pore waters, after which $P / R$ ratio in the seagrass meadow decreases below 1, indicating a shift from autotrophy to heterotrophy with sediment nutrient enrichment. Such a regime shift indicates a loss of storage capacity of the seagrass ecosystem, jeopardizing the key role of $P$. oceanica as a carbon sink in the Mediterranean.
\end{abstract}

KEY WORDS: Carbon sink · Eutrophication · Metabolism · Sediment $\cdot$ Threshold $\cdot$ Primary production

\section{INTRODUCTION}

Seagrass ecosystems are being increasingly considered to be amongst the largest carbon (C) sinks in the ocean (Nellemann et al. 2009). It has recently been estimated that the global mean gross primary production (GPP) to respiration $(R)$ ratio $(\mathrm{GPP} / R$, hereafter simply $P / R$ ) of a seagrass meadow is $1.55( \pm 0.13 \mathrm{SE})$, with $63 \%$ of available data on seagrass metabolism pointing to $P / R$ ratios $>1$ (Duarte et al. 2010). Since a $P / R$ ratio equal to 1 indicates metabolic balance, the majority of seagrass ecosystems sequester $\mathrm{C}$ in excess of consumption. A significant part of this excess is stored in seagrass sediments (Duarte \& Cebrian 1996), where it can remain for millennia (Mateo et al. 2006), and seagrass meadows bury on average 48 to $112 \mathrm{Tg} \mathrm{C} \mathrm{yr}{ }^{-1}$, which renders them hotspots for carbon sequestration (Kennedy et al. 2010). Duarte et al. (2010) estimated that the mean $P / R$ ratio of a Posidonia oceanica meadow is 1.78 , indicating that the dominant seagrass in the Mediterranean (Gobert et al. 2006) represents a crucial C sink for the basin. 
P. oceanica meadows constitute 1 to $2 \%$ of the Mediterranean sea bottom, usually extending up to $40 \mathrm{~m}$ depth and covering a total area of $50000 \mathrm{~km}^{2}$ (Bethoux \& Copin-Montegu 1986). These meadows are often millenary years old (Mateo et al. 1997) and are considered very important for coastal protection and conservation, being hotspots for biodiversity (Hemminga \& Duarte 2000).

Undisturbed sediments colonized by Posidonia oceanica are characterized by high carbon but low nitrogen (N) and phosphorus (P) deposition, with maximum values reported in spring (Gacia et al. 2002), and slow, mainly aerobic, mineralization rates (Barron et al. 2006). However, the annual sedimentary input of $\mathrm{N}$ and $\mathrm{P}$ in undisturbed $\mathrm{P}$. oceanica meadows has been reported to equal the annual demand for growth (Gacia et al. 2002). Hence, sedimentation constitutes a significant part of nutrient input to the meadow, through mineralization of sedimentary organic matter which supplies the seagrasses with pore water nutrients necessary for growth. $P$. oceanica seagrass seems to buffer nutrient limitation on an annual basis by nutrient storage and translocation within the clone (Alcoverro et al. 2000), being well adapted to the oligotrophic regime in the Mediterranean.

Nutrient enrichment of the coastal zone (Nixon 1995) has resulted in gross decline of Posidonia oceanica meadows across the Mediterranean (Boudouresque et al. 2009). Fish farm discharges, in particular, cause severe damage to $P$. oceanica meadows growing nearby (Delgado et al. 1999, Dimech et al. 2002, Marbà et al. 2006, Pergent-Martini et al. 2006, Holmer et al. 2008, Apostolaki et al. 2009, Ruiz et al. 2010). When extending near fish cages, $P$. oceanica meadows receive a significant amount of particulate organic matter discharged from these cages (Holmer et al. 2008). Available studies show that excessive nutrient inputs are deposited beneath the cages (Sarà et al. 2004, Holmer et al. 2007), increasing the sediment (Apostolaki et al. 2007) and the pore-water (Cancemi et al. 2003) nutrient pools. Redox potential is usually decreased, while sulfate reduction rate is stimulated (Holmer et al. 2003a), leading to an increase of sulfide pools in both the sediment (Pérez et al. 2007) and pore water (Calleja et al. 2007). Sulfides can invade seagrass roots (Frederiksen et al. 2008), inducing seagrass decline (Borum et al. 2005).

Díaz-Almela et al. (2008) have related sediment nutrient enrichment from fish farm effluents to an increase in shoot mortality and a decrease in shoot recruitment in Posidonia oceanica meadows across the Mediterranean. It is expected that nutrient enrichment from fish farm discharges also leads to a decrease in seagrass metabolism. A decrease in the metabolism of the seagrass ecosystem has been shown in case of organic loading (Holmer et al. 2004), low light availability (Gacia et al. 2005, Calleja et al. 2006) and fertilization from seabirds (Herbert \& Fourqurean 2008). P. oceanica ecosystems (i.e. composed of the seagrass and the associated epiphytes, as well as benthic microalgae, benthic fauna, bacteria and phytoplankton) growing near fish cages also show a decrease in both GPP and $R$ (Apostolaki et al. $2010 b)$. However, it is still unknown whether this decrease is related to nutrient enrichment of the sediment. In fact, the relationship between sediment nutrient enrichment from fish farm effluents and ecosystem metabolism has never been studied before for any seagrass species.

The temporal variation of organic matter from fish farms released and deposited on nearby sediment on an annual scale is still unknown. Most studies have been conducted only during summer (Pergent et al. 1999, Ruiz et al. 2001, Cancemi et al. 2003, Holmer et al. 2004, Sarà et al. 2004, Apostolaki et al. 2007, Holmer \& Frederiksen 2007, Holmer et al. 2008). Research effort has been focused on the warm period, as fish farm production and feed supply are increased during the summer, causing enhancement of fish farm effluents in the same period (Karakassis et al. 1998). Yet, fish farm production continues throughout the year, constantly releasing effluents to the surrounding environment. It can be expected that seasonal fluctuation in sediment nutrient enrichment might interfere with the annual cycle of seagrass metabolism, jeopardizing the key role of Posidonia oceanica ecosystems in carbon sequestration and cycling in the Mediterranean.

The present paper aims at examining whether the capacity of a Posidonia oceanica ecosystem to sequester carbon, using the ecosystem $P / R$ ratio as proxy, is modified when sediment is nutrient enriched from fish farm effluents. To this end, the temporal variation of $\mathrm{C}, \mathrm{N}$ and $\mathrm{P}$ sedimentation rate, of $\mathrm{C}, \mathrm{N}$ and $\mathrm{P}$ pools in the sediment and of $\mathrm{N}$ (ammonium, $\mathrm{NH}_{4}{ }^{+}$) and $\mathrm{P}$ (phosphate, $\mathrm{PO}_{4}{ }^{-3}$ ) concentration in the pore water were studied in a fish-farming impacted and in an unaffected $P$. oceanica meadow, during one year. $\mathrm{C}, \mathrm{N}$ and $\mathrm{P}$ sedimentation rates, nutrient pools in sediment and dissolved nutrients in pore water were correlated with the ecosystem $P / R$ ratio. Ecosystem $P / R$ ratios were calculated from GPP and $R$ previously published by Apostolaki et al. (2010b). 


\section{MATERIALS AND METHODS}

\section{Sampling strategy}

The study was conducted in a Posidonia oceanica meadow in Sounion $\left(37^{\circ} 39.55^{\prime} \mathrm{N}, 23^{\circ} 58.24^{\prime} \mathrm{E}\right)$, Aegean Sea, Greece, from June 2006 until April 2007. The site was characterized by coarse sand $(0.45$ to $0.90 \mathrm{~mm}$ mean diameter pore size), a low percentage of silt and/or clay (4.63 to $4.83 \%$ ), oxic conditions (292 to $353 \mathrm{mV}$ redox potential) (Apostolaki et al. 2007) and $5.5 \mathrm{~cm} \mathrm{~s}^{-1}$ mean bottom current speed (Holmer et al. 2007). At the time of the study, the fish farm had been operating for $10 \mathrm{yr}$, producing on average 400 tons $\mathrm{yr}^{-1}$ of gilthead sea bream Sparus aurata and sea bass Dicentrarchus labrax. Ten years before the present study, in 1996 when the fish farm had just been set up, the meadow extended up to the edge of the cages (I. Karakassis pers. obs.), whereas in 2006, the meadow had regressed $\sim 20 \mathrm{~m}$ from the edge of the cages, showing clear signs of disturbance due to fish farm effluents. Indeed, a series of abiotic (water column and sediment nutrients) and biotic (seagrass shoot density, biomass and growth) variables revealed that fish farming activities had affected the meadow (Holmer et al. 2008 and references therein), which showed decreased production and increased mortality $20 \mathrm{~m}$ away from the cages (Marbà et al. 2006, Díaz-Almela et al. 2008, Apostolaki et al. 2009). Hence, we selected one station (hereafter called 'cages') which was located as close to the fish cages as possible (around $20 \mathrm{~m}$ away) at a depth of $16 \mathrm{~m}$. Although Ruiz et al. (2010) detected a dispersion of farm wastes over several kilometres, a dialysis bag experiment at the study site showed that nutrient concentration in the water column decreased significantly $500 \mathrm{~m}$ away from the fish cages (Pitta et al. 2009), implying that the spatial extent of fish-farming impact in our case is smaller. Furthermore, Holmer et al. (2008) analyzed a series of variables in the water column, sediment, seagrass and benthic fauna from 4 sites, including our study site, and suggested that fish-farming impact is evident up to $400 \mathrm{~m}$ from the cages. Hence, we selected a reference station (hereafter called 'control') outside the area affected by fish farm waste, located $1 \mathrm{~km}$ away from the cages and at a depth of $14.5 \mathrm{~m}$. The site was visited every $2 \mathrm{mo}$ (from June 2006 until April 2007).

Benthic sediment traps (5 replicates) were deployed by divers during each sampling event for $48 \mathrm{~h}$, as described by Gacia et al. (1999), for the determination of particulate $\mathrm{C}, \mathrm{N}$ and $\mathrm{P}$ sedimentation rates. The traps were deployed just above the seagrass canopy and along the direction of the main water currents. Each trap consisted of a $20 \mathrm{ml}$ cylindrical centrifugation tube with an aspect ratio of 5 (i.d. = $16 \mathrm{~mm})$, in order to prevent internal resuspension. Sediment cores ( 3 replicates, i.d. $=4.5 \mathrm{~cm}$ each) were collected for the determination of surface (0 to $2 \mathrm{~cm}$ ) total organic $\mathrm{C}, \mathrm{N}$ and $\mathrm{P}$ concentrations. Pore water samples (3 replicates, $60 \mathrm{ml}$ each) were taken using an acid-washed syringe with a perforated sipper which collected pore water from a sediment depth of 1 to $10 \mathrm{~cm}$ for determination of ammonium $\left(\mathrm{NH}_{4}{ }^{+}\right)$ and phosphate $\left(\mathrm{PO}_{4}{ }^{3-}\right)$.

\section{Laboratory analysis}

In the laboratory, the particulate content of each sediment trap was filtered with pre-combusted and pre-weighted filters (Whatman GF/F). Each filter was dried at $60^{\circ} \mathrm{C}$ to constant weight and weighted. C and $\mathrm{N}$ in filters and sediment samples were measured using a Perkin Elmer 2400 CHN Analyzer (Hedges \& Stern 1984). Total P concentration in filters and sediment samples was determined using hydrochloric acid (Burton \& Riley 1956) and then analysed colorimetrically using molybdate solution (Strickland \& Parsons 1972). Pore water samples were filtered (Whatman GF/F), kept frozen and later analyzed for $\mathrm{NH}_{4}{ }^{+}$(Ivančič \& Deggobis 1984) and $\mathrm{PO}_{4}{ }^{-3}$ (Strickland \& Parsons 1972).

Particulate carbon, nitrogen and phosphorus sedimentation rate $\mathrm{SR}_{i}\left(\mathrm{mg} \mathrm{m} \mathrm{m}^{-2} \mathrm{~d}^{-1}\right)$ in each sampling event (i) was estimated as:

$$
\mathrm{SR}_{i}=\left(\mathrm{W}_{i} \times \mathrm{C}_{i}\right) d^{-1} t^{-1},
$$

where $\mathrm{W}_{i}$ is the weight of the particulate material collected in the sediment trap (in $\mathrm{mg}$ ), $\mathrm{C}_{i}$ is the concentration of carbon, nitrogen or phosphorus (as \% dry $\mathrm{wt}$ ), $d$ is the internal diameter (in $\mathrm{m}$ ) of the tube and $t$ is the time of deployment (in d).

Concurrent with sediment sampling, ecosystem $P / R$ was calculated for each sampling event and station. Estimates for GPP and $R$ were obtained from Apostolaki et al. (2010b). Briefly, GPP and $R$ were determined following oxygen evolution for $24 \mathrm{~h}$ using in situ benthic chambers. Benthic chambers ( 5 l) consisted of a PVC cylinder, a gas-tight polyethylene plastic bag and a sampling port to collect water samples. These chambers are widely used in metabolism studies (Duarte et al. 2002, Barrón et al. 2004) because they allow conduction of time-course experiments without dilution, continuous stirring, or gaseous head-space (Hansen et al. 2000), while they 
allow turbulence in the interior of the bag ensuring mixing (Barrón et al. 2006). The cylinders were slowly and carefully inserted in the sediment without cutting the rhizomes but rather pushing them down to the sediment, causing minimal sediment disturbance in comparison to other methods like laboratory incubations. Water samples were analyzed for dissolved oxygen concentration using the Winkler titration method. Oxygen units were converted to carbon units by assuming photosynthetic and respiratory quotients of 1.2 and 1.1, respectively (Oviatt et al. 1986).

\section{Data analysis}

Differences in $\mathrm{C}, \mathrm{N}$ and $\mathrm{P}$ sedimentation rates, $\mathrm{C}, \mathrm{N}$ and $\mathrm{P}$ concentration in the sediment, $\mathrm{NH}_{4}{ }^{+}$and $\mathrm{PO}_{4}{ }^{-3}$ pore water concentrations and ecosystem $P / R$ ratio between the cages and control stations in different sampling events were assessed by means of a 2-way ANOVA. If significant differences $(p<0.05)$ occurred among sampling events, a Tukey's post hoc test was used to identify which events were different from each other. Regression analysis was used in order to detect possible relationships between the tested variables (which were $\log _{10}$ transformed when necessary).

\section{RESULTS}

C sedimentation rate and sediment $\mathrm{C}$ concentration, $\mathrm{N}$ sedimentation rate, sediment $\mathrm{N}$ and pore water $\mathrm{NH}_{4}{ }^{+}$, and $\mathrm{P}$ sedimentation rate, sediment $\mathrm{P}$ and pore water $\mathrm{PO}_{4}{ }^{-3}$ were significantly and positively intercorrelated (Table 1).

Station (i.e. proximity to the cages) had a significant effect on $\mathrm{C}$ sedimentation rate, but the effect depended significantly on time of year (Table 2). The difference was due to the higher sedimentation rate at the cages station during the warm months (June, August and October; Table 2). In each sampling event, $\mathrm{C}$ sedimentation rate and sediment $\mathrm{C}$ were higher at the cages station than at the control station (Fig. 1). On an annual basis, C sedimentation rates were 4 times higher in sediments located at the cages station than in those at the control station. Mean C concentration in the sediment beneath the cages was 14 times higher than that measured at the control station.

$\mathrm{N}$ sediment concentrations were significantly enhanced at the cages station compared to the control station throughout the year (Fig. 2, Table 2). $\mathrm{N}$ sedimentation rate differed significantly between stations, depending on time, which differentiated October from December samplings (Table 2). Annual $\mathrm{N}$ sedimentation rate was 3 times higher at the cages station than at the control station. Average $\mathrm{N}$ concentration in the sediment was 9 times and in the pore water 2 times higher compared to the control.

$\mathrm{P}$ sediment inputs and sediment concentrations were significantly higher at the cages station than at the control station throughout the year (Fig. 3, Table 2). Station significantly affected pore water $P$, but the effect depended on time; June differed from August, October and April samplings (Table 2). On an annual scale, $\mathrm{P}$ in sedimentation rate was 4 -fold higher at the cages station compared to the control. The sediment and pore water concentrations were on average 1.3- and 3-fold, respectively, higher at the cages compared to the control.

Ecosystem $P / R$ ratio (Table 3 ) was significantly lower at the cages station compared to the control station (2-way ANOVA, Station: $F=4.94, \mathrm{p}=0.036$, Time: $F=1.39, \mathrm{p}=0.266$, Station $\times$ Time: $F=0.49, \mathrm{p}=$ $0.778)$. Annually, $P / R$ ratio was 1.3 and 1.7 at the cages and control station, respectively. $P / R$ ratio of the seagrass ecosystem decreased exponentially with increasing $\mathrm{C}, \mathrm{N}$ and $\mathrm{P}$ sedimentation rates, $\mathrm{C}, \mathrm{N}$ and $\mathrm{P}$ sediment concentrations and increasing $\mathrm{N}$ and $\mathrm{P}$ pools in pore water (Fig. 4).

Table 1. Linear regression coefficients and significance levels between carbon, nitrogen $(\mathrm{N})$ and phosphorus pools in sedimentation, sediment and pore water. The relationship between variables is described by the equation: $\log _{10} y=a+b \times \log _{10} X$, except the $\mathrm{N}$ sedimentation rate and pore water relationship which is described by the equation: $\log _{10} \mathrm{~N}$ sedimentation rate $=1 /\left(a+b / \log _{10}\right.$ Pore water $\left.N\right)$

\begin{tabular}{|llcccc|}
\hline$y$ & $x$ & $a$ & $b$ & $\mathrm{R}^{2}$ & $\mathrm{p}$ \\
\hline Carbon & & & & & \\
Sediment & Sedimentation rate & -2.004 & 1.104 & 0.57 & 0.004 \\
Nitrogen & & & & & \\
Sediment & Sedimentation rate & -2.091 & 1.228 & 0.59 & 0.009 \\
Pore water & Sedimentation rate & -2.091 & 4.849 & 0.45 & 0.034 \\
Pore water & Sediment & 0.813 & 0.291 & 0.50 & 0.023 \\
Phosphorus & & & & & \\
Sediment & Sedimentation rate & -1.629 & 0.143 & 0.51 & 0.009 \\
Pore water & Sedimentation rate & 0.324 & 0.490 & 0.46 & 0.015 \\
Pore water & Sediment & 3.919 & 2.210 & 0.37 & 0.035 \\
\hline
\end{tabular}


Table 2. ANOVA and Tukey's post hoc analysis results for carbon, nitrogen and phosphorus sedimentation rate and sediment concentrations and pore water nutrients (ammonium, $\mathrm{NH}_{4}{ }^{+}$and phosphate, $\mathrm{PO}_{4}{ }^{-3}$ ) between cages and control stations, at different sampling events

\begin{tabular}{|c|c|c|c|c|c|c|}
\hline & $\begin{array}{l}\text { Source of } \\
\text { variability }\end{array}$ & $\mathrm{df}$ & $\begin{array}{c}\text { ANOVA } \\
\text { MS }\end{array}$ & $F$ & $\mathrm{p}$ & Tukey's post hoc \\
\hline \multicolumn{7}{|l|}{ Carbon } \\
\hline $\begin{array}{l}\text { Sedimentation } \\
\text { rate }\end{array}$ & $\begin{array}{l}\text { Time }(\mathrm{T}) \\
\text { Station }(\mathrm{S}) \\
\mathrm{T} \times \mathrm{S}\end{array}$ & $\begin{array}{l}5 \\
1 \\
5\end{array}$ & $\begin{array}{c}32323 \\
371246 \\
15718\end{array}$ & $\begin{array}{c}10.33 \\
118.65 \\
5.02\end{array}$ & $\begin{array}{r}<0.001 \\
<0.001 \\
0.001\end{array}$ & $\begin{array}{l}\text { Jun } 06 \neq \mathrm{Dec}_{i} \\
\text { Oct } \neq \text { Aug, Dec, } \\
\text { Feb, Apr 07; }\end{array}$ \\
\hline Sediment & $\begin{array}{l}\text { Time } \\
\text { Station } \\
\mathrm{T} \times \mathrm{S}\end{array}$ & $\begin{array}{l}5 \\
1 \\
5\end{array}$ & $\begin{array}{c}2.68 \\
230.08 \\
2.38\end{array}$ & $\begin{array}{c}2.40 \\
205.46 \\
2.13\end{array}$ & $\begin{array}{r}0.067 \\
<0.001 \\
0.097\end{array}$ & $\mathrm{Dec} \neq \mathrm{Feb}$ \\
\hline \multicolumn{7}{|l|}{ Nitrogen } \\
\hline $\begin{array}{l}\text { Sedimentation } \\
\text { rate }\end{array}$ & $\begin{array}{l}\text { Time } \\
\text { Station } \\
\mathrm{T} \times \mathrm{S}\end{array}$ & $\begin{array}{l}5 \\
1 \\
5\end{array}$ & $\begin{array}{c}77.28 \\
2486.65 \\
79.06\end{array}$ & $\begin{array}{c}3.20 \\
102.91 \\
3.27\end{array}$ & $\begin{array}{r}0.015 \\
<0.001 \\
0.013\end{array}$ & Oct $\neq$ Dec \\
\hline Sediment & $\begin{array}{l}\text { Time } \\
\text { Station } \\
\mathrm{T} \times \mathrm{S}\end{array}$ & $\begin{array}{l}5 \\
1 \\
5\end{array}$ & $\begin{array}{l}0.02 \\
0.34 \\
0.02\end{array}$ & $\begin{array}{c}1.71 \\
27.07 \\
1.59\end{array}$ & $\begin{array}{r}0.171 \\
<0.001 \\
0.201\end{array}$ & \\
\hline Pore water & $\begin{array}{l}\text { Time } \\
\text { Station } \\
\mathrm{T} \times \mathrm{S}\end{array}$ & $\begin{array}{l}4 \\
1 \\
4\end{array}$ & $\begin{array}{c}2.18 \\
14.51 \\
4.93\end{array}$ & $\begin{array}{c}1.96 \\
13.06 \\
4.44\end{array}$ & $\begin{array}{l}0.153 \\
0.003 \\
0.015\end{array}$ & \\
\hline $\begin{array}{l}\text { Phosphorus } \\
\text { Sedimentation } \\
\text { rate }\end{array}$ & $\begin{array}{l}\text { Time } \\
\text { Station } \\
\mathrm{T} \times \mathrm{S}\end{array}$ & $\begin{array}{l}5 \\
1 \\
5\end{array}$ & $\begin{array}{c}1.38 \\
28.13 \\
1.35\end{array}$ & $\begin{array}{c}2.76 \\
56.37 \\
2.70\end{array}$ & $\begin{array}{r}0.030 \\
<0.001 \\
0.033\end{array}$ & \\
\hline Sediment & $\begin{array}{l}\text { Time } \\
\text { Station } \\
\mathrm{T} \times \mathrm{S}\end{array}$ & $\begin{array}{l}5 \\
1 \\
5\end{array}$ & $\begin{array}{c}0.00002 \\
0.0004 \\
0.0000\end{array}$ & $\begin{array}{c}1.72 \\
32.01 \\
1.22\end{array}$ & $\begin{array}{r}0.168 \\
<0.001 \\
0.329\end{array}$ & \\
\hline Pore water & $\begin{array}{l}\text { Time } \\
\text { Station } \\
\mathrm{T} \times \mathrm{S}\end{array}$ & $\begin{array}{l}5 \\
1 \\
5\end{array}$ & $\begin{array}{c}2.23 \\
41.39 \\
0.62\end{array}$ & $\begin{array}{c}3.82 \\
70.75 \\
1.07\end{array}$ & $\begin{array}{r}0.012 \\
<0.001 \\
0.404\end{array}$ & $\begin{array}{l}\text { Jun } 06 \neq \text { Aug, Oct } \\
\text { Apr } 07\end{array}$ \\
\hline
\end{tabular}

\section{DISCUSSION}

The temporal fluctuation in $\mathrm{C}, \mathrm{N}$ and $\mathrm{P}$ sedimentation rates (higher from June until October and lower in December) may reflect the seasonality in fish farm effluent release. Release of effluents is usually higher during the warm season in the Mediterranean (summer-autumn) as a result of the enhancement in fish farm production during this period (Karakassis et al. 1998). Similar studies in the Mediterranean basin have also reported higher sedimentation during summer, driven by loss of waste products from the fish cages, and subsequent sediment and pore water enrichment (Cancemi et al. 2003, Sarà et al. 2004, Apostolaki et al. 2007, Holmer \& Frederiksen 2007, Holmer et al. 2008). In the present study, however, we found that also during winter, nutrient deposition and accumulation in the sediments and pore waters were higher at the cages station compared to the control station. This suggests a continuous nutrient enrichment around the cages throughout the year, or at least that the reduction in feed supply during the cold period is not enough to allow a recovery of the benthic environment.

$\mathrm{C}$ pools in sedimentation and sediment, $\mathrm{N}$ pools in sedimentation, sediment and pore water and $\mathrm{P}$ pools in sedimentation, sediment and pore water were positively correlated, indicating a close linkage between $\mathrm{C}, \mathrm{N}, \mathrm{P}$ inputs and sediment nutrient pools in seagrass meadows, as suggested by de Boer (2007). The increase in $\mathrm{C}$ and $\mathrm{N}$ sediment pools at the cages station was higher than the increase in $\mathrm{P}$, possibly reflecting a faster remineralization and uptake of $\mathrm{P}$ than $\mathrm{C}$ and $\mathrm{N}$. The lack of $\mathrm{P}$ accumulation compared to $\mathrm{C}$ and $\mathrm{N}$ suggests that seagrass nutrient dynamics respond differently to nutrient enrichment. This result supports previous findings showing that nutrient limitation in seagrasses depends on specific plant features and local conditions (Romero et al. 2006). N concentration in seagrass leaves at the control station $1.7 \%$ dry wt, obtained by Apostolaki et al. 2009) was close to the threshold of $1.8 \%$ dry wt for no N limitation in seagrass growth (Duarte 1990), and $\mathrm{N}$ enrichment from fish farming would probably not stimulate uptake of $\mathrm{N}$ by the seagrasses. On the contrary, P concentration in seagrass leaves at the control station $(0.08 \%$ dry wt, obtained by Apostolaki et al. 2009) was substantially lower than $0.2 \%$ dry wt, the critical P content below which seagrasses are P deficient (Duarte 1990). It can thus be expected that Posidonia oceanica acquires P rapidly when this nutrient is available (Agawin et al. 1996, Alcoverro et al. 1997, Udy \& Dennison 1997). Indeed, increased P availability is often measured under nutrient enriched conditions (Apostolaki et al. 2010a,b). Under such conditions, sulfate reduction rates in the sediments are often intensified by the organic enrichment (Holmer \& Frederiksen 2007). Increased sediment sulfide production releases $\mathrm{P}$ bound to oxidized iron (Heijs et al. 2000) and P can then be taken up from pore water or the water column by the sea- 

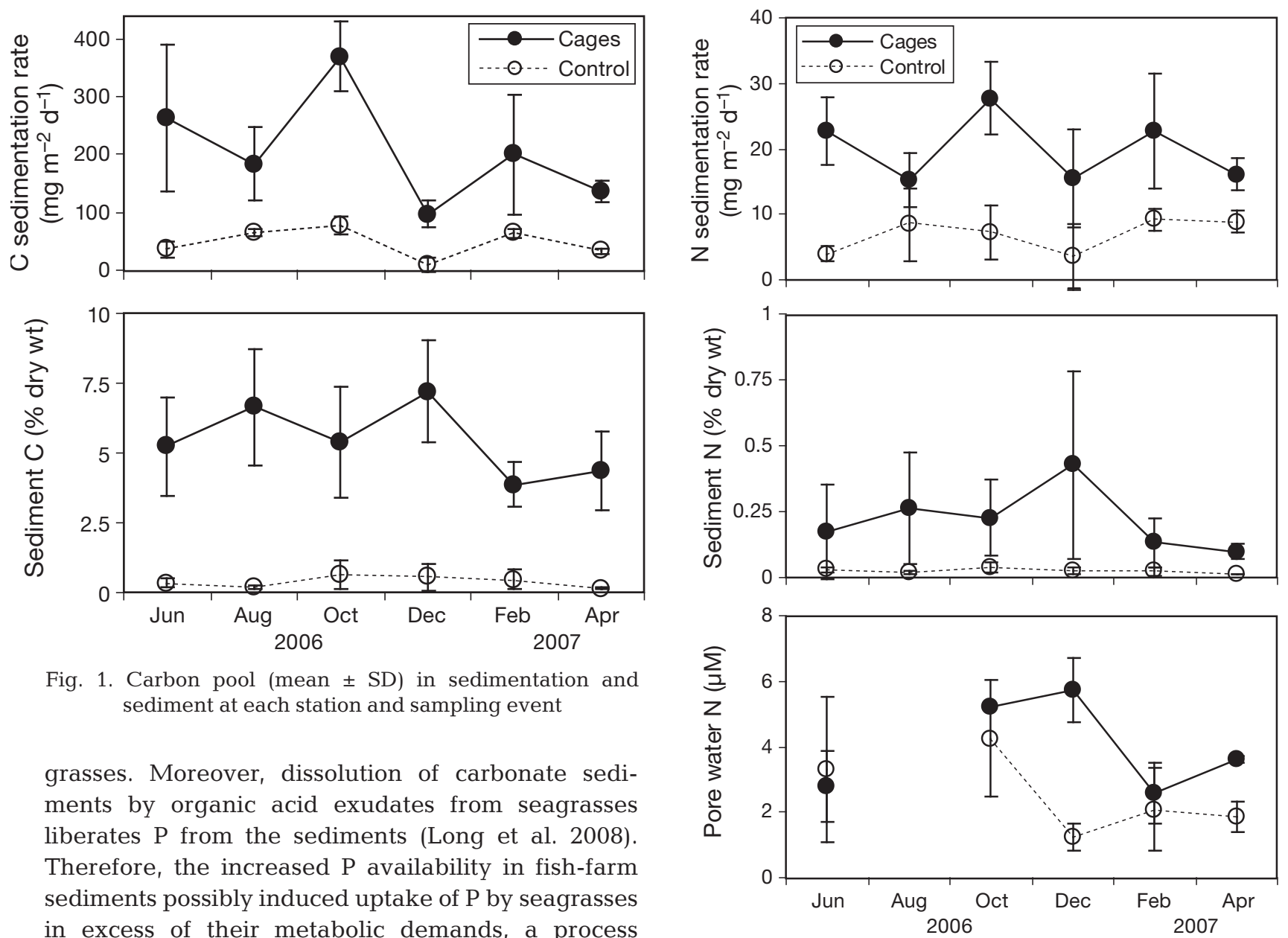

grasses. Moreover, dissolution of carbonate sediments by organic acid exudates from seagrasses liberates P from the sediments (Long et al. 2008). Therefore, the increased $\mathrm{P}$ availability in fish-farm sediments possibly induced uptake of $\mathrm{P}$ by seagrasses in excess of their metabolic demands, a process known as 'luxury consumption' (Romero et al. 2006) which has been reported for seagrasses (Ferdie \& Fourqurean 2004) and other primary producers (Romero et al. 2006). Luxury uptake and storage of $P$ in seagrass tissue possibly resulted in lower accumulation of $\mathrm{P}$ in sediment at the cages station.

The increase in seagrass leaf $P$ concentration at the cages station did not lead to increased seagrass standing crop (annual mean 38.05 and $166.62 \mathrm{~g} \mathrm{~m}^{-2}$ at cages and control station, respectively; obtained from Apostolaki et al. 2009). On the contrary, seagrass standing crop decreased with increasing leaf $\mathrm{P}$ content (linear regression, intercept $=511$, slope $=$ $-5803, \mathrm{R}^{2}=0.73, \mathrm{p}<0.001$ ), implying that the excess nutrient supply was not capitalized into shoot growth. This excess was not capitalized into ecosystem production either, as shown by the reduced ecosystem $P / R$ ratio upon nutrient enrichment. Holmer et al. (2004) have measured a similar decrease in net community production (NCP) of a Posidonia oceanica meadow impacted by organic inputs. Deposition and accumulation of organic matter and nutrients in seagrass sediments (Díaz-Almela et al. 2008, Pérez et al.

Fig. 2. Nitrogen pool (mean $\pm \mathrm{SD}$ ) in sedimentation, sediment and pore water at each station and sampling event

2008) reduce seagrass photosynthetic capacity and subsequent production of carbon reserves (Burkholder et al. 1994, Ruiz et al. 2001, Invers et al. 2004). An increase in sulfide pools in the sediments along with a decrease in NCP has been shown in tropical seagrass meadows (Gacia et al. 2005, Calleja et al. 2006), suggesting interference of sulfides in seagrass metabolism. Increasing sulfide pools in the sediment (Pérez et al. 2007) and pore water (Calleja et al. 2007), lead to seagrass decline (Borum et al. 2005, Frederiksen et al. 2007, 2008, Mascaró et al. 2009).

Excess $\mathrm{C}$ originated from fish farm discharges is not likely to counterbalance the loss of $\mathrm{C}$ production in the impacted meadow. The biochemical composition of organic matter accumulated in the sediment beneath fish cages is different, being enriched in organic C and lipids (Pusceddu et al. 2007). Bacterial consumption of $\mathrm{C}$ was probably enhanced (Danovaro et al. 2003), accelerating C cycling (López et al. 1995, 1998). Epiphytes, which are known to contribute sig- 

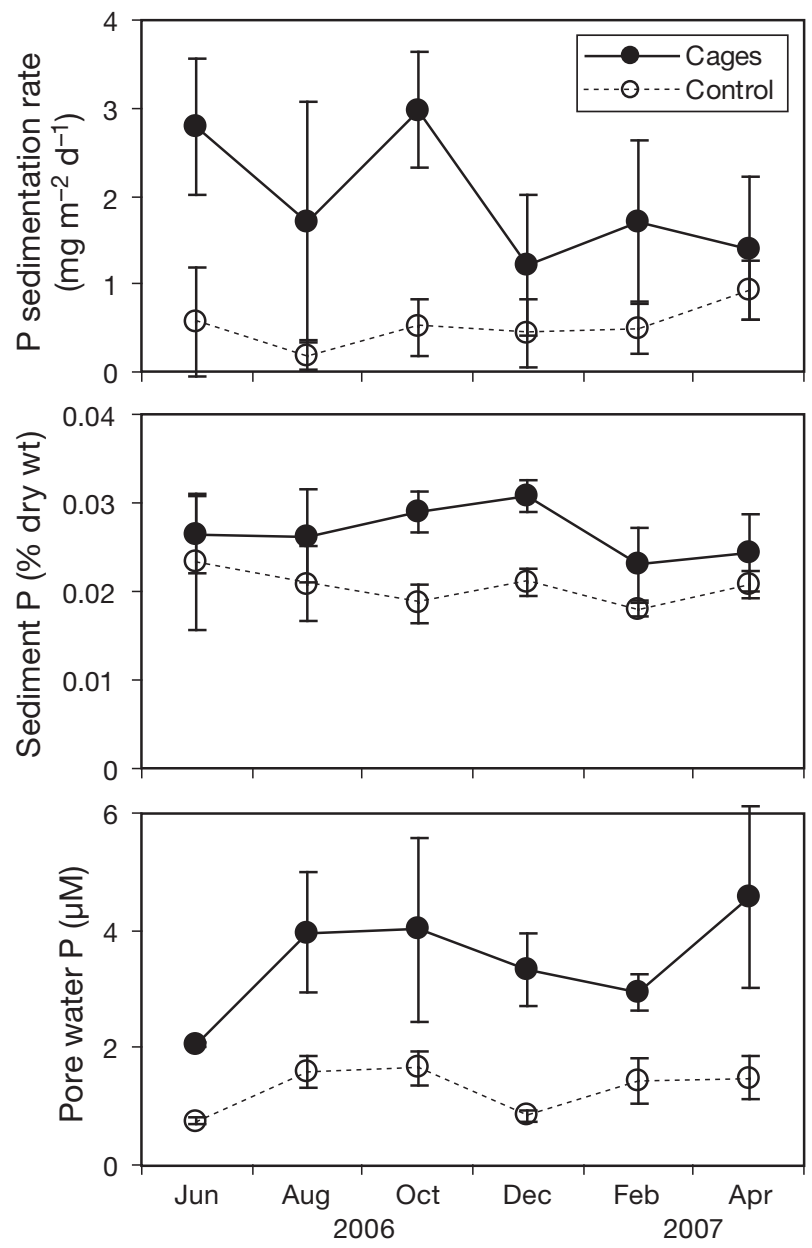

Fig. 3. Phosphorus pool (mean $\pm \mathrm{SD}$ ) in sedimentation, sediment and pore water at each station and sampling event

Table 3. Gross primary production (GPP; mean $\pm \mathrm{SD})$, respiration $(R)$ and $P / R$ ratio $(P=\mathrm{GPP})$, at each station and sampling event. GPP and $R$ values were obtained from Apostolaki et al. (2010a)

\begin{tabular}{|lccc|}
\hline \multicolumn{5}{c}{\begin{tabular}{c}
$\mathrm{GPP}$ \\
\multicolumn{4}{c}{$\left(\mathrm{mmol} \mathrm{C} \mathrm{m}^{-2} \mathrm{~d}^{-1}\right)$}
\end{tabular}} & $\begin{array}{c}R \\
\left(\mathrm{mmol} \mathrm{C} \mathrm{m}^{-2} \mathrm{~d}^{-1}\right)\end{array}$ \\
\hline Cages & & & $P / R$ \\
Jun 06 & $45.32( \pm 26.11)$ & $33.92( \pm 23.86)$ & $1.45( \pm 0.26)$ \\
Aug & $72.33( \pm 17.9)$ & $49.89( \pm 15.02)$ & $1.47( \pm 0.21)$ \\
Oct & $12.21( \pm 12.49)$ & $9.57( \pm 13.25)$ & $0.84( \pm 1.41)$ \\
Dec & $32.11( \pm 9.4)$ & $31.76( \pm 15.52)$ & $1.08( \pm 0.24)$ \\
Feb 07 & $76.96( \pm 9.84)$ & $51.72( \pm 15.32)$ & $1.53( \pm 0.23)$ \\
Apr & $68.08( \pm 23.32)$ & $50.79( \pm 11.01)$ & $1.38( \pm 0.49)$ \\
Control & & & \\
Jun 06 & $176.71( \pm 32.28)$ & $117.31( \pm 24.61)$ & $1.51( \pm 0.04)$ \\
Aug & $91.77( \pm 13.74)$ & $63.92( \pm 3.32)$ & $1.43( \pm 0.14)$ \\
Oct & $75.24( \pm 8.3)$ & $52.71( \pm 4.51)$ & $1.43( \pm 0.04)$ \\
Dec & $62.09( \pm 6.29)$ & $37.86( \pm 3.52)$ & $1.64( \pm 0.12)$ \\
Feb 07 & $58.74( \pm 9.03)$ & $28.11( \pm 0.58)$ & $2.09( \pm 0.31)$ \\
Apr & $85.59( \pm 5.76)$ & $47.24( \pm 4.16)$ & $1.81( \pm 0.04)$ \\
\hline
\end{tabular}

nificantly to seagrass ecosystem production (Borowitzka et al. 2006, Ouisse et al. 2010), were not related to either $\mathrm{C}$ production or consumption (Apostolaki et al. 2011). In contrast, NCP decreased with decreasing

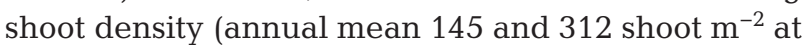
cages and control station, respectively; obtained from Apostolaki et al. 2009) close to the fish cages (linear regression, intercept $=-1.22$, slope $=0.10, R^{2}=0.52$, $\mathrm{p}<0.01$ ), indicating declining metabolic activity of the seagrass ecosystem upon sediment nutrient enrichment. It is suggested, therefore, that the decrease in $P / R$ ratio is mainly driven by the decline of the seagrass, which is the key species of the ecosystem.

Our results indicate that ecosystem $P / R$ ratio decreased exponentially in response to increasing nutrient enrichment, and was below 1 at the cages station, causing a threshold response with an ecosystem shift from autotrophy to heterotrophy. Several ecosystems show threshold responses to severe environmental change and modulate between alternative states (Andersen et al. 2009). The present results suggest that at this particular site a shift from autotrophy to heterotrophy occurs when sedimentation rates exceed 391, 34 and $34 \mathrm{mg} \mathrm{m}^{-2} \mathrm{~d}^{-1}$ of $\mathrm{C}, \mathrm{N}$ and $\mathrm{P}$, respectively, when sediment pools exceed 10, 0.4 and $0.03 \%$ dry wt of $\mathrm{C}, \mathrm{N}$ and $\mathrm{P}$, respectively, and when $\mathrm{NH}_{4}{ }^{+}$and $\mathrm{PO}_{4}{ }^{-3}$ in pore water surpass $6 \mu \mathrm{M}$.

These thresholds should be extrapolated with caution to other Posidonia oceanica ecosystems, since they derive from measurements in a single meadow. Nonetheless, Holmer at al. (2008 and references therein) studied the effect of fish farming on this and 3 more $P$. oceanica meadows (in Cyprus, Italy and Spain) by measuring a series of abiotic (water column and sediment nutrients) and biotic (benthic fauna and seagrass) variables. They concluded that fish farm discharges had similar impacts on the seagrass ecosystem near the fish cages, despite the fact that site and fish farm characteristics differed (depth, temperature, bottom current, farm size, annual fish production, food input and waste production). Moreover, Díaz-Almela et al. (2008) suggested a similar threshold for P sedimentation $\left(50 \mathrm{mg} \mathrm{P} \mathrm{m}^{-2} \mathrm{~d}^{-1}\right)$, after which shoot mortality accelerates and shoot recruitment declines substantially. Therefore, despite a lack of site replication, our results appear indicative of fish-farming impact on carbon sequestration in $P$. oceanica communities.

A regime shift to heterotrophy with the continuation of sediment nutrient enrichment from fish farm discharges would eventually cause carbon sequestration to cease in impacted Posidonia oceanica sediments. Healthy P. oceanica ecosystems are known to 

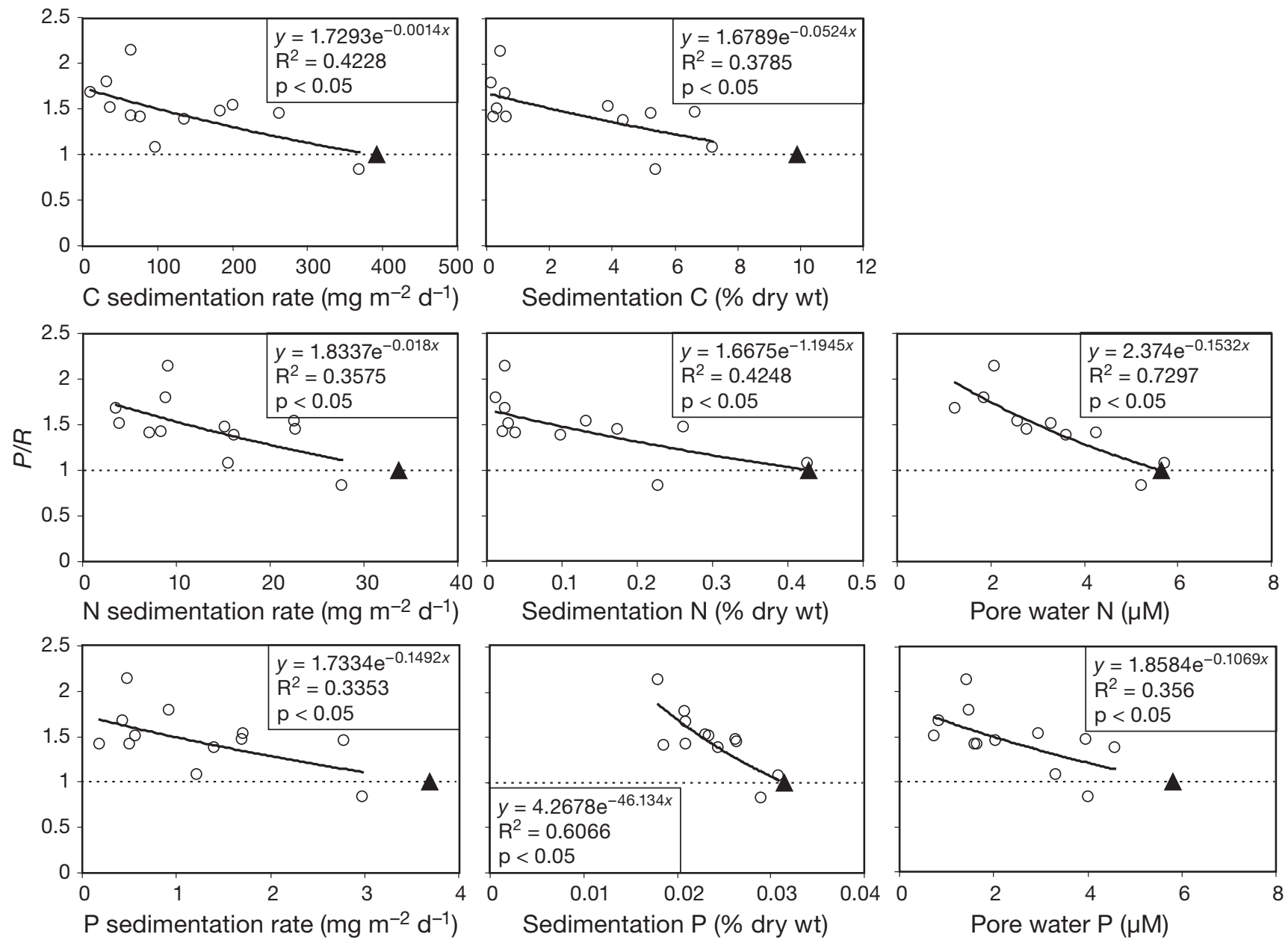

Fig. 4. Exponential reduction in $P / R$ ratio with increasing carbon, nitrogen or phosphorus pools in sedimentation, sediment and pore water. Significance levels ( $p$-values) are given. $\boldsymbol{\Delta}$ : threshold value after which the community shifts to heterotrophy

sequester annually more carbon than unvegetated (i.e void of seagrass or macroalgae) communities (Barrón et al. 2006, Barrón \& Duarte 2009), implying that considerably more carbon is stored in P. oceanica than in bare sediments. In our case, the control meadow showed 9 times higher annual NCP than the adjacent unvegetated community (Apostolaki et al. 2010b), emphasizing the high $C$ sink capacity of this meadow. Duarte et al. (2010) suggested that $1 / 3$ of the global carbon sink capacity of seagrasses has been lost due to a global decrease of $29 \%$ in seagrass area since seagrass areas were initially recorded in 1879 (Waycott et al. 2009). Furthermore, P. oceanica is a slow-growing species with a very slow recovery rate (Marbà et al. 2002), meaning that its full recovery is usually considered irreversible in human time scale (Marbà et al. 2005). It is therefore essential to restore and protect $P$. oceanica meadows, in order to fulfil their key role in carbon cycling and storage in the Mediterranean, by adopting efficient regulation of human pressures such as fish farming. Monitoring of sedimentation, as also suggested by Holmer et al. (2008), as well as sediment and pore water nutrient pools are effective and reliable tools for managing seagrasses near fish farms. This is particularly important to consider in order to achieve sustainable fish farming activities along the Mediterranean coasts, since the future of aquaculture is expected to increase significantly (Duarte et al. 2009) to meet the increasing demand of animal proteins for the rapidly increasing human population.

Acknowledgements. This work was co-funded by the EUEuropean Social Fund (75\%) and the Greek Ministry of Development-GSRT (25\%) (IBIS Project). Thanks are due to T. Tsagaraki, I. Glabedakis, V. Pefanis-Vassilatos, N. Kouroubalis and V. Stasinos for assistance with sampling and E. Dafnomili for assistance in chemical analyses. We are grateful to 3 anonymous reviewers for helpful comments and criticism on the manuscript. 


\section{LITERATURE CITED}

Agawin NSR, Duarte CM, Fortes MD (1996) Nutrient limitation of Philippine seagrasses (Capo Bolinao, NW Philippines): in situ experimental evidence. Mar Ecol Prog Ser 138:233-243

> Alcoverro T, Romero J, Duarte CM, López NI (1997) Spatial and temporal variations in nutrient limitation of seagrass Posidonia oceanica growth in the NW Mediterranean. Mar Ecol Prog Ser 146:155-161

Alcoverro T, Manzanera M, Romero J (2000) Nutrient mass balance of the seagrass Posidonia oceanica: the importance of nutrient translocation. Mar Ecol Prog Ser 194: $13-21$

Andersen T, Carstensen J, Hernandez-Garcia E, Duarte CM (2009) Ecological thresholds and regime shifts: approaches to identification. Trends Ecol Evol 24:49-57

> Apostolaki ET, Tsagaraki T, Tsapakis M, Karakassis I (2007) Fish farming impact on sediments and macrofauna associated with seagrass meadows in the Mediterranean. Estuar Coast Shelf Sci 75:408-416

> Apostolaki ET, Marbà N, Holmer M, Karakassis I (2009) Fish farming enhances biomass and nutrient loss in Posidonia oceanica (L.) Delile. Estuar Coast Shelf Sci 81:390-400

Apostolaki ET, Holmer M, Marbà N, Karakassis I (2010a) Degrading seagrass (Posidonia oceanica) ecosystems: a source of dissolved matter to the Mediterranean. Hydrobiologia 649:13-23

Apostolaki ET, Holmer M, Marbà N, Karakassis I (2010b) Metabolic imbalance in coastal vegetated (Posidonia oceanica) and unvegetated benthic ecosystems. Ecosystems 13:459-471

> Apostolaki ET, Holmer M, Marbà N, Karakassis I (2011) Epiphyte dynamics and carbon metabolism in a nutrient enriched Mediterranean seagrass (Posidonia oceanica) ecosystem. J Sea Res 66:135-142

Barrón C, Duarte CM (2009) Dissolved organic matter release in a Posidonia oceanica meadow. Mar Ecol Prog Ser 374:75-84

Barrón C, Marbà N, Terrados J, Kennedy H, Duarte CM (2004) Community metabolism and carbon budget along a gradient of seagrass (Cymodocea nodosa) colonization. Limnol Oceanogr 49:1642-1651

Barrón C, Duarte CM, Frankignoulle M, Borges AV (2006) Organic carbon metabolism and carbonate dynamics in a Mediterranean seagrass (Posidonia oceanica) meadow. Estuaries Coasts 29:417-426

> Bethoux JP, Copin-Montegu G (1986) Biological fixation of atmospheric nitrogen in the Mediterranean Sea. Limnol Oceanogr 31:1353-1358

Borowitzka MA, Lavery PS, van Keulen M (2006) Epiphytes of seagrasses. In: Larkum AWD, Orth RJ, Duarte CM (eds) Seagrasses: biology, ecology and conservation. Springer, Dordrecht, p 441-461

> Borum J, Pedersen O, Greve TM, Frankovich TA, Zieman JC, Fourqourean JW, Madden CJ (2005) The potential role of plant oxygen and sulphide dynamics in die-off events of the tropical seagrass, Thalassia testudinum. J Ecol 93:148-158

> Boudouresque CF, Bernard G, Pergent G, Shili A, Verlaque M (2009) Regression of Mediterranean seagrasses caused by natural processes and anthropogenic disturbances and stress: a critical review. Bot Mar 52:395-418

Burkholder JM, Glasgow HB Jr, Cooke JE (1994) Comparative effects of water-column nitrate enrichment on eel- grass Zostera marina, shoalgrass Halodule wrightii, and widgeongrass Ruppia maritima. Mar Ecol Prog Ser 105: 121-138

Burton JD, Riley JP (1956) Determination of soluble phosphate, and total phosphorus in sea-water and of total phosphorus in marine muds. Mikrochim Acta 44: 1350-1365

Calleja ML, Barrón C, Hale JA, Frazer TK, Duarte CM (2006) Light regulation of benthic sulfate reduction rates mediated by seagrass (Thalassia testudinum) metabolism. Estuaries Coasts 29:1255-1264

> Calleja ML, Marbà N, Duarte CM (2007) The relationship between seagrass (Posidonia oceanica) decline and sulfide porewater concentration in carbonate sediments. Estuar Coast Shelf Sci 73:583-588

Cancemi G, De Falco G, Pergent G (2003) Effects of organic input from a fish farm facility on a Posidonia oceanica meadow. Estuar Coast Shelf Sci 56:961-968

Danovaro R, Corinaldesi C, La Rosa T, Luna GM and others (2003) Aquaculture impact on benthic microbes and organic matter cycling in coastal Mediterranean sediments: a synthesis. Chem Ecol 19:59-65

de Boer WF (2007) Seagrass-sediment interactions, positive feedbacks and critical thresholds for occurrence: a review. Hydrobiologia 591:5-24

Delgado O, Ruiz JM, Pérez M, Romero J, Ballesteros E (1999) Effects of fish farming on seagrass (Posidonia oceanica) in a Mediterranean bay: seagrass decline after organic loading cessation. Oceanol Acta 22:109-117

Díaz-Almela E, Marbà N, Álvarez E, Santiago R and others (2008) Benthic input rates predict seagrass (Posidonia oceanica) fish farm-induced decline. Mar Pollut Bul 56: 1332-1342

Dimech M, Borg JA, Schembri PJ (2002) Changes in structure of a Posidonia oceanica meadow and in the diversity of associated decapod, mollusc and echinoderm assemblages, resulting from inputs of waste from a marine fish farm (Malta, Mediterranean Sea). Bull Mar Sci 71: 1309-1321

Duarte CM (1990) Seagrass nutrient content. Mar Ecol Prog Ser 67:201-207

Duarte CM, Cebrian J (1996) The fate of marine autotrophic production. Limnol Oceanogr 41:1758-1766

Duarte CM, Martínez R, Barrón C (2002) Biomass, production and rhizome growth near the northern limit of seagrass (Zostera marina) distribution. Aquat Bot 72 : 183-189

> Duarte CM, Holmer M, Olsen Y, Soto D and others (2009) Will the oceans help feed humanity? Bioscience 59: 967-976

> Duarte CM, Marbà N, Gacia E, Fourqurean JW, Beggins J, Barrón C, Apostolaki ET (2010) Seagrass community metabolism: assessing the carbon sink capacity of seagrass meadows. Global Biogeochem Cycles 24:GB4032, doi:10.1029/2010GB003793

> Ferdie M, Fourqurean JW (2004) Responses of seagrass communities to fertilization along a gradient of relative availability of nitrogen and phosphorus in a carbonate environment. Limnol Oceanogr 49:2082-2094

> Frederiksen M, Holmer M, Dìaz-Almela E, Marba N, Duarte CM (2007) Sulfide invasion in the seagrass Posidonia oceanica at Mediterranean fish farms: assessment using stable sulfur isotopes. Mar Ecol Prog Ser 345:93-104

Frederiksen M, Holmer M, Pérez M, Invers O, Ruiz JM, Knudsen BB (2008) Effect of increased sediment sulfide 
concentrations on the composition of stable sulfur isotopes $\left(\delta^{34} \mathrm{~S}\right)$ and sulfur accumulation in the seagrasses Zostera marina and Posidonia oceanica. J Exp Mar Biol Ecol 358:98-109

> Gacia E, Granata TC, Duarte CM (1999) An approach to measurement of particle flux and sediment retention within seagrass (Posidonia oceanica) meadows. Aquat Bot 65:255-268

Gacia E, Duarte CM, Middelburg JJ (2002) Carbon and nutrient deposition in a Mediterranean seagrass (Posidonia oceanica) meadow. Limnol Oceanogr 47:23-32

Gacia E, Kennedy H, Duarte CM, Terrados J, Marbà N, Papadimitriou S, Fortes M (2005) Light-dependence of the metabolic balance of a highly productive Philippine seagrass community. J Exp Mar Biol Ecol 316:55-67

Gobert S, Cambridge ML, Velimirov B, Pergent G and others (2006) Biology of Posidonia. In: Larkum AWD, Orth RJ, Duarte CM (eds) Seagrasses: biology, ecology and conservation. Springer, Dordrecht, p 387-408

> Hansen JW, Thamdrup B, Jørgensen BB (2000) Anoxic incubation of sediment in gas-tight plastic bags: a method for biogeochemical process studies. Mar Ecol Prog Ser 208: 273-282

Hedges JI, Stern JH (1984) Carbon and nitrogen determinations of carbonate-containing solids. Limnol Oceanogr 29:657-663

> Heijs SK, Azzoni R, Giordani G, Jonkers HM, Nizzoli D, Viaroli P, van Gemerden H (2000) Sulfide-induced release of phosphate from sediments of coastal lagoons and the possible relation to the disappearance of Ruppia sp. Aquat Microb Ecol 23:85-95

Hemminga MA, Duarte CM (2000) Seagrass ecology. Cambridge University Press, Cambridge

> Herbert DA, Fourqurean JW (2008) Ecosystem structure and function still altered 2 decades after short-term fertilization of a seagrass meadow. Ecosystems 11:688-700

> Holmer M, Frederiksen M (2007) Stimulation of sulfate reduction rates in Mediterranean fish farm sediments inhabited by the seagrass Posidonia oceanica. Biogeochemistry 85:169-184

> Holmer M, Duarte CM, Marba N (2003a) Sulfur cycling and seagrass (Posidonia oceanica) status in carbonate sediments. Biogeochemistry 66:223-239

Holmer M, Duarte CM, Boschker HTS, Barrón C (2004) Carbon cycling and bacterial carbon sources in pristine and impacted Mediterranean seagrass sediments. Aquat Microb Ecol 36:227-237

> Holmer M, Marba N, Diaz-Almela E, Duarte CM, Tsapakis M, Danovaro R (2007) Sedimentation of organic matter from fish farms in oligotrophic Mediterranean assessed through bulk and stable isotope $\left(\delta^{13} \mathrm{C}\right.$ and $\left.\delta^{15} \mathrm{~N}\right)$ analyses. Aquaculture 262:268-280

> Holmer M, Argyrou M, Dalsgaard T, Danovaro R and others (2008) Effects of fish farm waste on Posidonia oceanica meadows: synthesis and provision of monitoring and management tools. Mar Pollut Bul 56:1618-1629

Invers O, Kraemer GP, Pérez M, Romero J (2004) Effects of nitrogen addition on nitrogen metabolism and carbon reserves in the temperate seagrass Posidonia oceanica. J Exp Mar Biol Ecol 303:97-114

Ivančič I, Deggobis D (1984) An optimal manual procedure for ammonia analysis in natural waters by the indophenol blue method. Water Res 18:1143-1147

Karakassis I, Tsapakis M, Hatziyanni E (1998) Seasonal variability in sediment profiles beneath fish farm cages in the
Mediterranean. Mar Ecol Prog Ser 162:243-252

> Kennedy H, Beggins J, Duarte CM, Fourqurean JW, Holmer M, Marbà N, Middelburg JJ (2010) Seagrass sediments as a global carbon sink: isotopic constraints. Global Biogeochem Cycles 24:GB4026 doi:10.1029/2010GB003848

Long MH, McGlathery KJ, Zieman JC, Berg P (2008) The role of organic acid exudates in liberating phosphorus from seagrass-vegetated carbonate sediments. Limnol Oceanogr 53:2616-2626

> López NI, Duarte CM, Vallespinós F, Romero J, Alcoverro T (1995) Bacterial activity in NW Mediterranean seagrass (Posidonia oceanica) sediments. J Exp Mar Biol Ecol 187: $39-49$

López NI, Duarte CM, Vallespinós F, Romero J, Alcoverro T (1998) The effect of nutrient additions on bacterial activity in seagrass (Posidonia oceanica) sediments. J Exp Mar Biol Ecol 224:155-166

> Marbà N, Duarte CM, Holmer M, Martínez R and others (2002) Effectiveness of protection of seagrass (Posidonia oceanica) populations in Cabrera National Park (Spain). Environ Conserv 29:509-518

> Marbà N, Duarte CM, Díaz-Almela E, Terrados J and others (2005) Direct evidence of imbalanced seagrass (Posidonia oceanica) shoot population dynamics in the Spanish Mediterranean. Estuaries 28:53-62

Marbà N, Santiago R, Díaz-Almela E, Álvarez E, Duarte CM (2006) Seagrass (Posidonia oceanica) vertical growth as an early indicator of fish-farm-derived stress. Estuar Coast Shelf Sci 67:475-483

> Mascaró O, Valdemarsen T, Holmer M, Pérez M, Romero J (2009) Experimental manipulation of sediment organic content and water column aeration reduces Zostera marina (eelgrass) growth and survival. J Exp Mar Biol Ecol 373:26-34

> Mateo MA, Romero J, Pérez M, Littler MM, Littler DS (1997) Dynamics of millenary organic deposits resulting from the growth of the Mediterranean seagrass Posidonia oceanica. Estuar Coast Shelf Sci 44:103-110

Mateo MA, Cebrian J, Dunton KH, Mutchler T (2006) Carbon flux in seagrass ecosystems. In: Larkum AWD, Orth RJ, Duarte CM (eds) Seagrasses: biology, ecology and conservation. Springer, Dordrecht, p 227-254

Nellemann C, Corcoran E, Duarte CM, Valdés L, De Young C, Fonseca L, Grimsditch G (eds) (2009) Blue carbon. The role of healthy oceans in binding carbon. A rapid response assessment. United Nations Environment Programme, GRID-Arendal, Arendal

Nixon SW (1995) Coastal marine eutrophication-a definition, social causes, and future concerns. Ophelia 41:199-219

Ouisse V, Migné A, Davoult D (2010) Seasonal variations of community production, respiration and biomass of different primary producers in an intertidal Zostera noltii bed (western English Channel, France). Hydrobiologia 649: 3-11

Oviatt CA, Rudnick DT, Keller AA, Sampou PA, Almquist GT (1986) A comparison of system $\left(\mathrm{O}_{2}\right.$ and $\left.\mathrm{CO}_{2}\right)$ and C14 measurements of metabolism in estuarine mesocosms. Mar Ecol Prog Ser 28:57-67

Pérez M, Invers O, Ruiz JM, Frederiksen M, Holmer M (2007) Physiological responses of the seagrass Posidonia oceanica to elevated organic matter content in sediments: an experimental assessment. J Exp Mar Biol Ecol 344:149-160

Pérez M, García T, Invers O, Ruiz JM (2008) Physiological responses of the seagrass Posidonia oceanica as indica- 
tors of fish farm impact. Mar Pollut Bul 56:869-879

Pergent G, Mendez S, Pergent-Martini C, Pasqualini V (1999) Preliminary data on the impact of fish farming facilities on Posidonia oceanica meadows in the Mediterranean. Oceanol Acta 22:95-107

Pergent-Martini C, Boudouresque CF, Pasqualini V, Pergent G (2006) Impact of fish farming facilities on Posidonia oceanica meadows: a review. PSZN I: Mar Ecol 27: 310-319

Pitta P, Tsapakis M, Apostolaki ET, Tsagaraki T, Holmer M, Karakassis I (2009) 'Ghost nutrients' from fish farms are transferred up the food web by phytoplankton grazers. Mar Ecol Prog Ser 374:1-6

Pusceddu A, Fraschetti S, Mirto S, Holmer M, Danovaro R (2007) Effects of intensive mariculture on sediment biochemistry. Ecol Appl 17:1366-1378

Romero J, Lee KS, Pérez M, Mateo MA, Alcoverro T (2006) Nutrient dynamics in seagrass ecosystems. In: Larkum AWD, Orth RJ, Duarte CM (eds) Seagrasses: biology, ecology and conservation. Springer, Dordrecht, p 227-254

Ruiz JM, Pérez M, Romero J (2001) Effects of fish farm load-

Editorial responsibility: Tim Dempster,

Trondheim, Norway ings on seagrass (Posidonia oceanica) Distribution, growth and photosynthesis. Mar Pollut Bul 42:749-760

Ruiz JM, Marco-Méndez C, Sánchez-Lizaso JL (2010) Remote influence of off-shore fish farm waste on Mediterranean seagrass (Posidonia oceanica) meadows. Mar Environ Res 69:118-126

Sarà G, Scilipoti D, Mazzola A, Modica A (2004) Effects of fish farming waste to sedimentary and particulate organic matter in a southern Mediterranean area (Gulf of Castellammare, Sicily): a multiple stable isotope study $\left(\delta^{13} \mathrm{C}\right.$ and $\left.\delta^{15} \mathrm{~N}\right)$. Aquaculture 234:199-213

Strickland JD, Parsons TR (1972) A practical handbook of sea-water analysis. Bull Fish Res Board Can 167

Udy JW, Dennison WC (1997) Growth and physiological responses of three seagrass species to elevated sediment nutrients in Moreton Bay, Australia. J Exp Mar Biol Ecol 217:253-277

Waycott M, Duarte CM, Carruthers TJB, Orth RJ and others (2009) Accelerating loss of seagrasses across the globe threatens coastal ecosystems. Proc Natl Acad Sci USA 106:12377-12381

Submitted: July 18, 2011; Accepted: September 13, 2011 Proofs received from author(s): October 6, 2011 